\title{
Combination between Acidity Amendments and Sewage Sludge with Phosphorus on Soil Chemical Characteristics and on Development of Castor Bean
}

Silvia Capuani, Dirceu Maximino Fernandes, João Paulo Gonsiorkiewicz Rigon \& Lívia Cristina Ribeiro

To cite this article: Silvia Capuani, Dirceu Maximino Fernandes, João Paulo Gonsiorkiewicz Rigon \& Lívia Cristina Ribeiro (2015) Combination between Acidity Amendments and Sewage Sludge with Phosphorus on Soil Chemical Characteristics and on Development of Castor Bean, Communications in Soil Science and Plant Analysis, 46:22, 2901-2912, DOI: 10.1080/00103624.2015.1104337

To link to this article: https://doi.org/10.1080/00103624.2015.1104337

Accepted author version posted online: 16

Oct 2015.

Published online: 30 Nov 2015.

Submit your article to this journal $\sqsubset$

Џll Article views: 117

View Crossmark data ¿

Citing articles: 3 View citing articles $\square$ 


\title{
Combination between Acidity Amendments and Sewage Sludge with Phosphorus on Soil Chemical Characteristics and on Development of Castor Bean
}

\author{
SILVIA CAPUANI@, DIRCEU MAXIMINO FERNANDES, \\ JOÃO PAULO GONSIORKIEWICZ RIGON॰, AND LÍVIA \\ CRISTINA RIBEIRO
}

College of Agricultural Sciences, São Paulo State University (UNESP), Botucatu, São Paulo, Brazil

\begin{abstract}
The addition of urban and industrial waste products to agriculture not only provides them with an adequate environmental destination but also increases the nutrient content and negative charges in the soil, especially in naturally acidic tropical soils with high phosphorus-fixing capacity, just as liming does in relation to the dependent charges of $\mathrm{pH}$. Both cases make it possible to favor the availability of phosphate fertilization. The aim of this study was to assess the interactions between application of composted sewage sludge (SSS) and soluble phosphorus (P) in combination with different rates of limestone (LS) and steel slag (SS) on the characteristics of dwarf castor bean and soil chemical properties. The experiment was conducted in a greenhouse in Botucatu, SP, Brazil. The Oxisol soil used was incubated with the combinations-based on chemical analyses of the soil, the waste product and slag, considering the needs of castor bean-in the 45 days prior to sowing, undertaking analysis of castor bean growth and dry-matter weight after physiological maturity, the time at which soil analysis was performed. SSS as an amendment of soil acidity provided better results in the properties of soil acidity, sum of bases (SB), cation exchange capacity (CEC), and base saturation (BS\%). The combinations of the amendments were similar in regard to the increase of $P$ availability in the soil. Although SSS alone resulted in an increase in organic matter $(O M)$, nitrogen $(N)$, magnesium $(M g)$, potassium $(K)$, boron (B), cupper ( $\mathrm{Cu})$, zinc $(\mathrm{Zn})$, and iron (Fe) contents in the soil, the low $P$ content in the waste product extended the castor bean cycle, requiring $P$ supplementation in combination.
\end{abstract}

Keywords Organic waste, phosphate fertilization, Ricinus communis L., silicate

\section{Introduction}

Among the oilseed crops, castor bean stands out as having one of the most versatile plant oils in nature, in addition to the possibility for its use in biodiesel production (Barnes, Baldwin, and Braasch 2009). In spite of great demand, the supply of oil for raw material is not sufficient to meet industry needs (Severino et al. 2012). Practically all castor bean crop production is concentrated in India, China, and Brazil, representing 95\% of production

Received 31 July 2014; accepted 4 May 2015

Address correspondence to João Paulo Gonsiorkiewicz Rigon, Sao Paulo State University (UNESP), College of Agricultural Sciences, 18603-970, Botucatu, SP, Brazil. E-mail: jprigon@ fca.unesp.br 
worldwide (Faostat 2011). In Brazil, planting large areas with castor bean has expanded in the center west and Brazilian Cerrado (tropical savanna) regions, with good yields. However, in spite of the increase in studies on the crop in recent years, detailed studies on its cultivation are lacking compared to other crops, especially in regard to soil fertility and plant growth.

Soil acidity affects nutrient availability and may condition deficiency and toxicity of chemical elements (Soratto and Crusciol 2008). Although limestone (LS) is the most commonly used amendment for correction of soil acidity in the country, steel slag (SS) is an efficient source for increasing $\mathrm{pH}$ and the level of exchangeable bases in the soil profile more rapidly than LS (Castro and Crusciol 2013). Industrial wastes such as SS are used in various countries with a great deal of viability in agriculture, while Brazil is beginning to consolidate this scenario (Prado and Fernandes 2001).

Steel slag (SS) consists of waste from steel production, with silicates of calcium and magnesium in its composition, which have the ability to neutralize acidity and allow displacement of these nutrients in the soil profile, in addition to iron $(\mathrm{Fe})$ and manganese $(\mathrm{Mn})$ oxides and other elements in lesser quantities (Carvalho-Pupatto, Büll and Crusciol 2004; Ramos et al. 2006). Another significant characteristic of SS in the soil is an increase in the efficiency of phosphorus (P) fertilization through its potential competition with the phosphate anion for the same soil adsorption sites (Prado and Fernandes 2001). Léles et al. (2010) observed an increase in the quantity of P released from the soil with the application of SS in comparison to LS at greater rates. Another waste product with potential for use in agriculture, combining activity as a fertilizer and soil conditioner, is stabilized sewage sludge (SSS), which may fully or partially take the place of mineral fertilization (Chiaradia et al. 2009).

Tropical soils are predominantly acidic, with low cation exchange capacity (CEC) and fertility, as well as high P-fixing capacity. The addition of organic waste is an alternative for adding nutrients and negative charges to the soil, as well as the indispensable use of soil amendments in relation to $\mathrm{pH}$-dependent charges; both factors promote phosphate fertilization. The aim of this study was to assess the interactions between application of composted sewage sludge (SSS) and soluble phosphorus (P), in combination with different application rates of limestone (LS) and steel slag (SS), on the characteristics of dwarf castor bean and on soil chemical properties and verify that the sewage sludge requires of soluble $\mathrm{P}$ supplementation and the different combinations of limes can reduce $\mathrm{P}$ adsorption sites make available in the soil solution.

\section{Materials and Methods}

The experiment was carried out in 2012 in a greenhouse at the School of Agronomic Sciences, FCA-UNESP, Lageado Experimental Farm, Botucatu, SP, Brazil. The soil used is classified as an Typic Haplustox (Soil Survey Staff 2010) of medium texture and low natural fertility.

A randomized block experimental design in a $4 \times 4$ factorial arrangement with four replicates was used, representing the factors of soil amendments $\times$ SSD and P, both combinations in the proportions of each treatment of $100 \%, 66 \%, 33 \%$, and $0 \%$ based on chemical analyses. The criterion for the proportions of soil amendments was raising the base saturation to $70 \%$ by combinations of LS and SS, with the chemical characteristics shown in Table 1. The combinations of SSS and P were based on the $\mathrm{N}$ needs of castor bean, together with a $\mathrm{N}$ mineralization capacity (TMN) of $30 \%$, according to the Environmental Sanitation Technology Company of the State of São Paulo (CETESB) and the P needs of castor bean. The SSS used was composted in sewage sludge treatment 


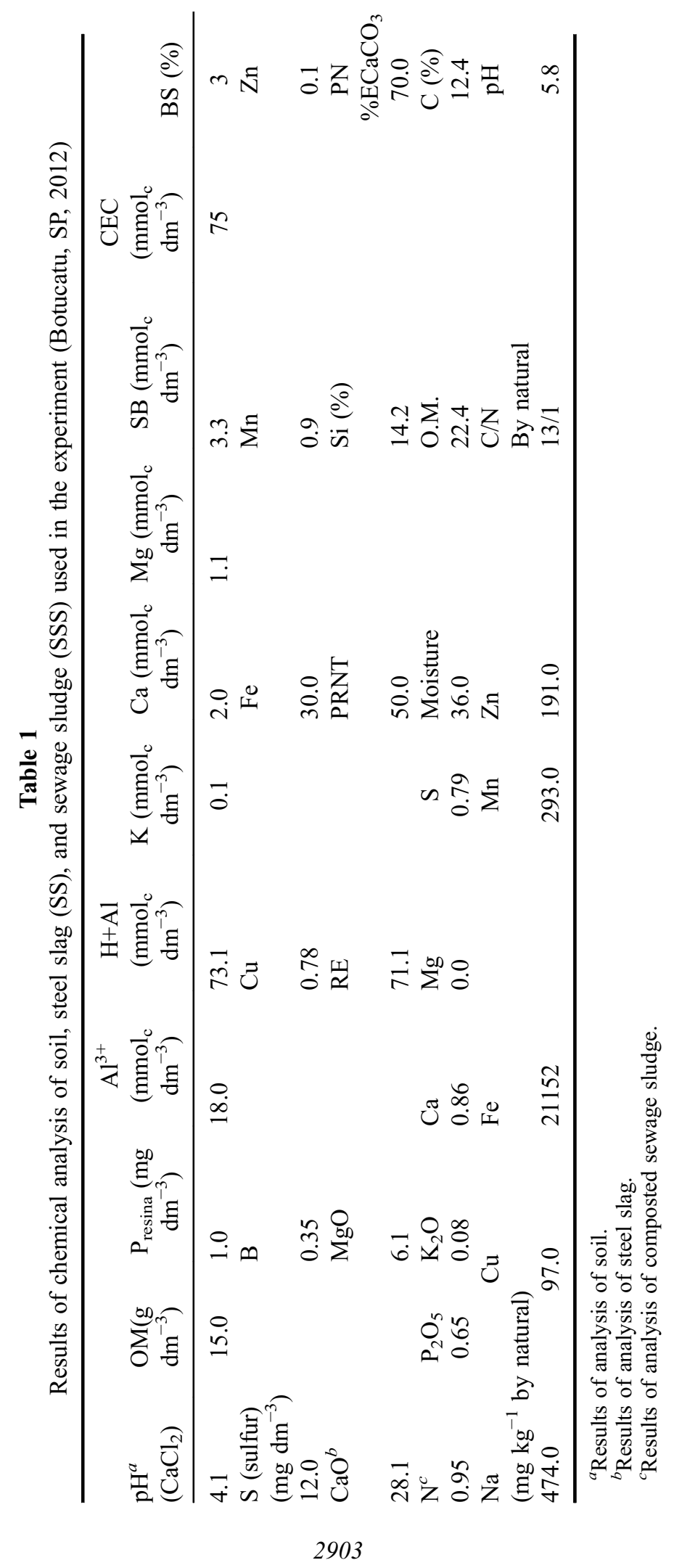


plant for met the quality requirements established by the National Environmental Council, CONAMA (Brazil 2006).

Pots with a volume of $40 \mathrm{dm}^{3}$ were used; the combinations were applied, and they were incubated for 45 days. After the period of incubation of the treatments and before sowing, the samples of soil were collected and the following chemical characteristics were analyzed according to Raij et al. (2001): (1) pH [calcium chlroide $\left(\mathrm{CaCl}_{2}\right) 0.01 \mathrm{~mol} \mathrm{~L}^{-1}$ ]; (2) organic matter (dry, OM); (3) P, calcium $(\mathrm{Ca})$, magnesium $(\mathrm{Mg})$, and potassium $(\mathrm{K})$ (ion exchange resin); (4) sum of bases ( $\mathrm{SB}, \mathrm{Ca}+\mathrm{Mg}+\mathrm{K}$ ); (5) cation exchange capacity [CEC, $\mathrm{Ca}+\mathrm{Mg}+\mathrm{K}+$ aluminum (Al)]; (6) base saturation (BS\%; SB $\times 100 / \mathrm{CEC})$; (7) copper $(\mathrm{Cu}), \mathrm{Fe}, \mathrm{Mn}$, zinc $(\mathrm{Zn})$, diethylene triamine pentaacetic acid (DTPA); (8) boron (B) (Abreu et al. 1994); (9) hydrogen and aluminum (H+Al), SMP (Quaggio, Van Raij, and Malavolta 1985); and (10) N (Tedesco, Volkweiss and Bohnen 1985).

Subsequently, $\mathrm{K}$ fertilization was carried out in all the treatments for the purpose of reaching $40 \mathrm{mg} \mathrm{dm}^{-3}$. Castor bean was then sown on 9 March using a stabilized dwarf line from the Department of Plant Production and Breeding of the FCA-UNESP, thinning the plants after 3 weeks to constitute one plant per experimental unit. Because of low OM content, $\mathrm{N}$ was supplied by topdressing through urea at a rate of $50 \mathrm{mg} \mathrm{kg}^{-1}$ in the five- to six-leaf stage at 20 days after plant emergence (DAE).

Assessments of castor bean growth were made every 2 weeks during the period of 25-85 DAE through measurement of plant height, stem diameter, and leaf area. At physiological maturity of the castor bean plant, soil macro- and micronutrients were analyzed in six subsamples per pot, for a total of one sample per experimental unit. The plants were then removed and separated into leaves, stalk, stem, and roots after sieving the soil and dried in an air circulation oven at $65^{\circ} \mathrm{C}$ for $72 \mathrm{~h}$.

Data were subjected to variance analysis by $\mathrm{F}$ test, and the means were compared using the Tukey's test at 0.05 probability. For the growth morphological characteristics, the data were fitted to regression models by SAS (SAS Institute, 2009). The fit degree was measured by the F-test analysis of variance and the coefficient of determination $\left(\mathrm{R}^{2}\right)$.

\section{Results}

\section{Morphological Characteristics}

Regardless of the growth variables analyzed, the combination of the $100 \%$ rate of SSS sludge with the omission of $\mathrm{P}$ in the first assessments led to the lowest mean values (Figures 1a and 1b). However, this treatment on the leaf area resulted in increasing mean values as determinations were carried out, culminating in the greatest value in the phase of physiological maturity of the last determination (Figure 1c).

\section{Dry-Matter Weight}

The biomass of the stalk and stem in the castor bean crop was not different among the treatments. In contrast, the dry-matter weights of leaves and the root were different as an effect of the combinations of SSS and P (Figure 2). It may be observed that the combinations of the maximum rates of SSS and P with their respective absences did not differ, resulting in greater dry-matter weight of leaves, just as had occurred for leaf area at the rate of $100 \% \mathrm{SSS} \times 0 \% \mathrm{P}$. 

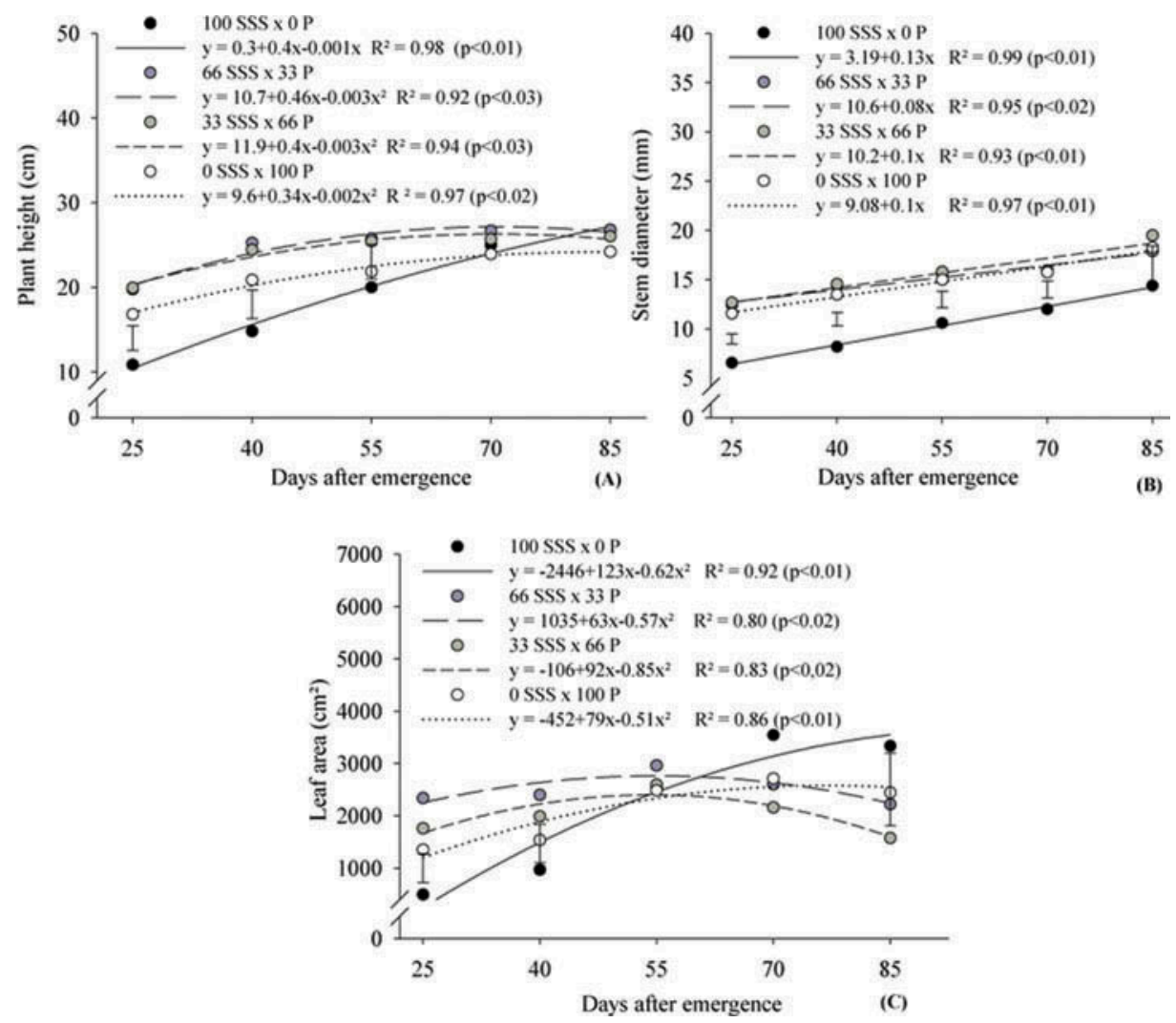

Figure 1. Plant height (A), stem diameter (B), and leaf area (C) during growth of castor bean in accordance with application rates of sewage sludge and phosphorus. Vertical bars correspond to LSD at $5 \%$ by the Tukey test.

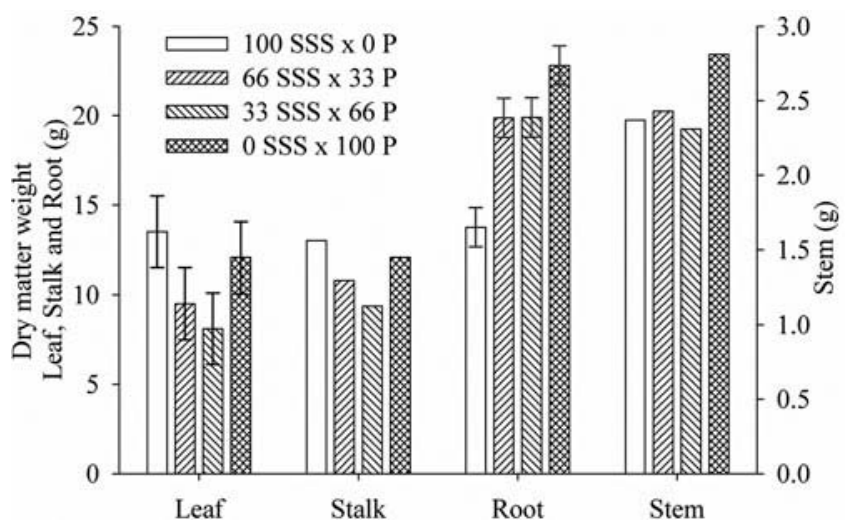

Figure 2. Dry-matter weight of castor bean in accordance with the combinations of SS and P. Vertical bars correspond to LSD at $5 \%$ by the Tukey test. 


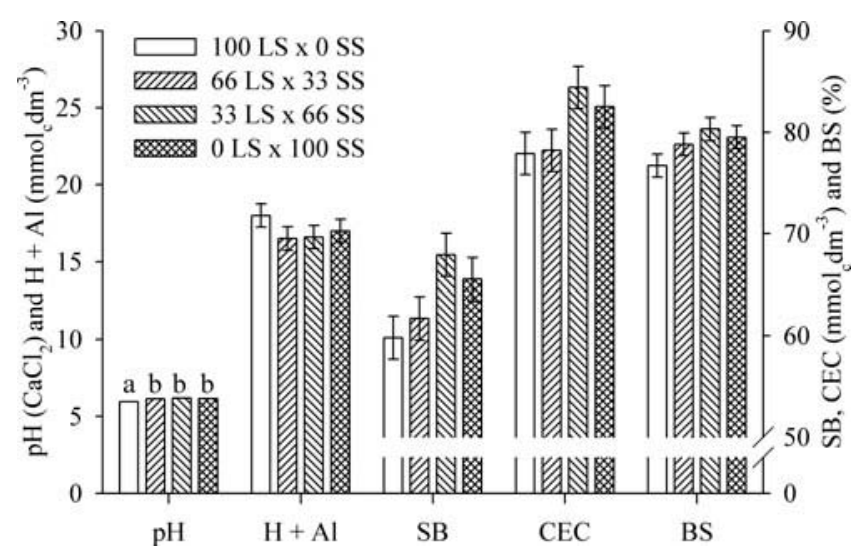

Figure 3. Level of $\mathrm{pH}$, potential acidity $(\mathrm{H}+\mathrm{Al})$, sum of bases $(\mathrm{SB})$, cation exchange capacity (CEC), and base saturation (BS\%) of the soil after the period of incubation of the treatments. Vertical bars correspond to LSD at $5 \%$ by the Tukey test.

\section{Soil Nutrients}

Soil acidity amendments increased the $\mathrm{pH}$ values; however, the efficiency of the combinations of steel slag after 45 days of incubation may be highlighted, resulting in greater SB, $\mathrm{CEC}$, and $\mathrm{BS} \%$, just as had occurred in reduction of potential acidity $(\mathrm{H}+\mathrm{Al})$ (Figure 3 ). There was no effect on these variables with respect to the combinations of SSS and P.

The use of a soil amendment led to an effect in the OM contents through the combination of $100 \%$ LS $+0 \%$ SS. Possibly, liming led to an increase in organic carbon and in other compartments of OM, as reported by Briedis et al. (2012).

The combinations between the soil amendments resulted in contrasting contents of $\mathrm{Mg}$ and $\mathrm{Ca}$ in the soil due to the large proportion of $\mathrm{Mg}$ in dolomitic limestone, as well as $\mathrm{Ca}$ in steel slag (Figure 4). As a result, the $\mathrm{Mg}$ contents decreased according to the increase in the steel slag rates in the combinations from 12 to $23 \mathrm{mmol}_{\mathrm{c}} \mathrm{dm}^{-3}$. The behavior of the

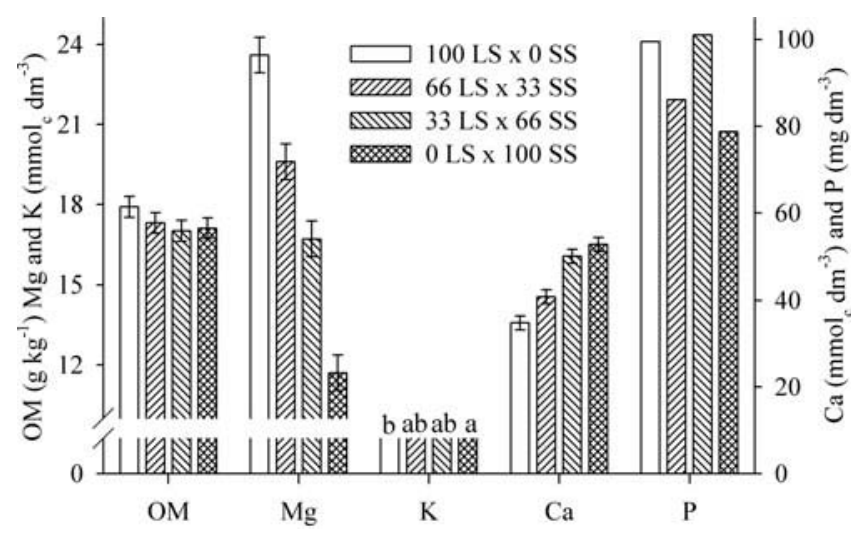

Figure 4. Contents of $\mathrm{OM}, \mathrm{Mg}, \mathrm{K}, \mathrm{Ca}$, and $\mathrm{P}$ in the soil according to the combinations of limestone and silicate after the period of soil incubation. Vertical bars correspond to LSD at $5 \%$ by the Tukey test. 
$\mathrm{Ca}$ contents was in an inverse manner to that observed for $\mathrm{Mg}$, increasing according to the steel slag rates from 38 to $55 \mathrm{mmol}_{\mathrm{c}} \mathrm{dm}^{-3}$.

In spite of the short time, the increasing proportions of SSS resulted in significant effects in the contents of $\mathrm{OM}, \mathrm{Mg}$, and $\mathrm{K}$, as well as in detriment a decrease in the growing proportions of $\mathrm{P}$ that complement the combinations of SSS, resulting in an increase in the element itself (Figure 5).

It may be observed that for $\mathrm{Mg}$, the rates of SSS resulted in high contents in the soil, while the absence of the waste product, combined with the maximum rate of $\mathrm{P}(0 \% \mathrm{SSS} \times$ $100 \% \mathrm{P}$ ), differed from the rest, resulting in a lower $\mathrm{Mg}$ content. Similar results were reported by Colodro and Espindola (2006).

\section{Micronutrients in the Soil}

The increasing amounts of SS resulted in an increase in B contents and especially in Mn contents, which ranged from 0.9 to $6.4 \mathrm{mg} \mathrm{dm}^{-3}$, while the most pronounced effects in the $\mathrm{Cu}$ and $\mathrm{Zn}$ contents arose from the effect of LS, which reduced according to the increase in the rates of silicate (Figure 6a). The greatest proportions of organic waste in the SSS and P

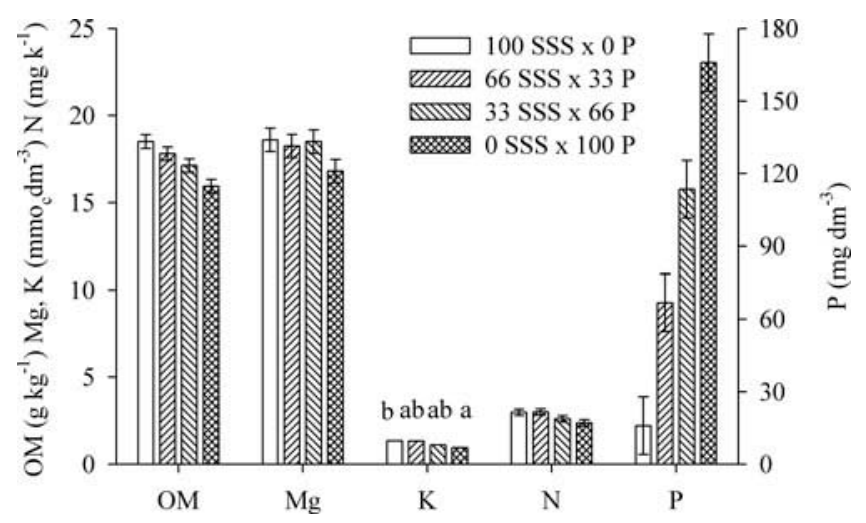

Figure 5. Contents of $\mathrm{OM}, \mathrm{Mg}, \mathrm{K}, \mathrm{N}$, and $\mathrm{P}$ in the soil according to the combinations of sewage sludge and phosphorus after the period of soil incubation. Vertical bars correspond to LSD at $5 \%$ by the Tukey test.

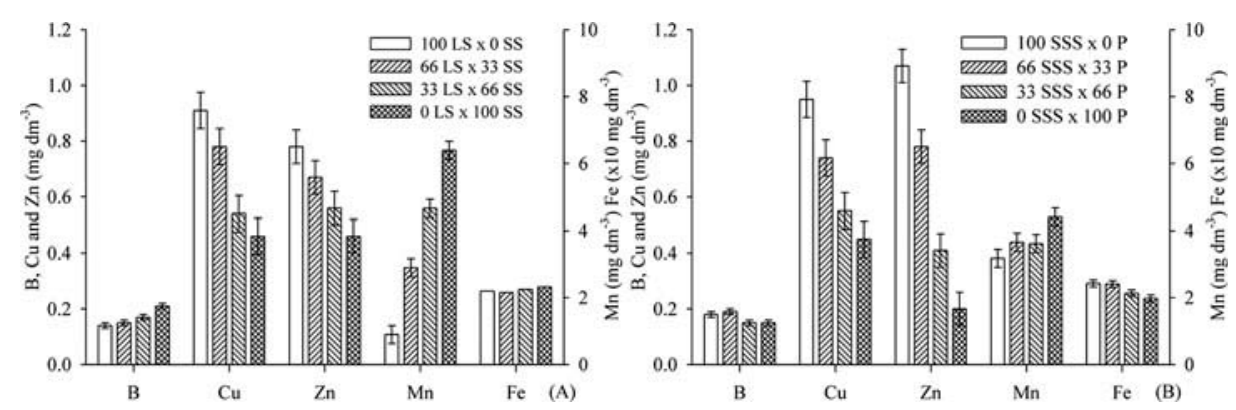

Figure 6. Micronutrient contents in the soil according to the combinations of limestone and silicate (A) and sewage sludge and phosphorus (B) after the period of soil incubation. Vertical bars correspond to LSD at $5 \%$ by the Tukey test. 
combinations resulted in an increase of micronutrient contents in the soil, except for $\mathrm{Mn}$, which had a decreasing response to the addition of SSS (Figure 6b).

\section{Discussion}

\section{Morphological Characteristics}

The less-pronounced growth stems from the low P content derived from the SSS and from the soil; for that reason, the combinations were responsible for the best mean values. In an experiment for the purpose of determining the effects of SSS on castor bean undertaken in a greenhouse in an Oxisol soil, the SSS did not make sufficient $\mathrm{P}$ available to change the concentration in the plant nor in the $\mathrm{P}$ content of the soil (Backes et al. 2009). Unsatisfactory $\mathrm{P}$ contents retard initial growth of the plant, which leads to a significant reduction in castor bean yield (Severino et al. 2006).

In spite of differences in height during the crop cycle, at physiological maturity, measurements were similar, but this was not the case for stem diameter in this period. Similar results in regard to stem diameter and castor bean height were observed by Almeida et al. (2009), with a direct relationship to the increase in $\mathrm{P}$ rates, although these characteristics are desirable for mechanized harvest.

The lower values in the initial determinations of leaf area through maximum SSS rates and $\mathrm{P}$ omission (Figure 1c) are related to the slow growth, which also stems from the low $\mathrm{P}$ contents in the soil and waste. Together with this, the $\mathrm{N}$ mineralization rate of the organic waste throughout the cycle may have had an effect on a greater photosynthetic apparatus of castor bean, which may be reflected in greater yield. Nitrogen has a strong effect on the size of the castor bean leaf. Reddy and Matcha (2010) observed an increase of 3.7-fold in leaf size and 1.4-fold in number. The fast vegetative growth in castor bean plants is important because it results in greater yields (Brum et al. 2011). Nevertheless, this pronounced vegetative growth may extend the cycle in soils with high $\mathrm{N}$ contents, and thus there may be excessive growth of leaves in castor bean, leading to self-shading, increasing the rate of castor bean senescence (Severino et al. 2012), while a uniform cycle is desirable for mechanized harvest.

These results demonstrate that $\mathrm{P}$ supplementation is required for growth of castor bean, even with application of SSS. Brito et al. (2014), in a study with different soil types, observed that the plant height, stem diameter, and leaf area of castor are directly influenced by the concentration of $\mathrm{P}$ in the soil, with the critical $\mathrm{P}$ concentrations of shoots indifferent between soils.

\section{Dry-Matter Weight}

It may be inferred that SSS made sufficient P available for development of the aboveground part of the plant, in contrast with the root, in which there was an increasing response to the addition of $\mathrm{P}$ in detriment to the rates of SSS, while the intermediate combinations did not differ among themselves. Similar results with an increase in dry matter in castor bean were observed by Oliveira et al. (2009) by means of fertilization with SSS.

\section{Soil Nutrients}

In an experiment that analyzed dolomitic LS, centrifuged SSS, aqueous lime, and SS, SS was the most effective in amendment of soil acidity (Corrêa et al. 2009). Carvalho- 
Pupatto, Büll, and Crusciol (2004) reported that the use of SS raised the $\mathrm{pH}$ values in a significant manner and reduced potential acidity of the soil. This is due to the neutralization power of other amendments such as SS not following the same behavior as LS (Ramos et al. 2006). This rapid effect may be explained by the manufacturing process, resulting in porous particles with a large specific area, with solubility from six to seven times greater than limestone (Alcarde and Rodella 2003).

The behavior of the $\mathrm{Ca}$ contents was in an inverse manner to that observed for $\mathrm{Mg}$, increasing according to the SS rates from 38 to $55 \mathrm{mmol}_{\mathrm{c}} \mathrm{dm}^{-3}$; this behavior is attributed to a reduction in the sites of its carriers, which are occupied by another nutrient (Malavolta 2006). For that reason, the combinations should be taken into consideration because they result in a more adequate balance of $\mathrm{Ca}$ and $\mathrm{Mg}$ in the soil. In spite of the high values observed, $\mathrm{K}$ contents ranged from 1.06 to $1.4 \mathrm{mmol}_{\mathrm{c}} \mathrm{dm}^{-3}$, with an effect of the presence of LS.

Because of the extremely low $\mathrm{P}$ content in the soil $\left(1.0 \mathrm{mg} \mathrm{dm}^{-3}\right)$, together with the absence content coming from the combination of $100 \mathrm{SSS} \times 0 \mathrm{P}$ (Figure 6) of $18.5 \mathrm{mg} \mathrm{dm}$ -3 , equating with the increase in the contents of this element obtained by combinations of soil amendments $\left(93.5 \mathrm{mg} \mathrm{dm}^{-3}\right)$, although they were not significantly different from each other, the potential of increasing $\mathrm{P}$ availability from the amendments may be highlighted. A result similar to SS in the increase of P availability was observed by Prado et al. (2002) in the increase in $\mathrm{pH}, \mathrm{Ca}$, and $\mathrm{Mg}$, as well as a reduction of $\mathrm{H}+\mathrm{Al}$ (Pulz et al. 2008), arising from soil acidity amendment by silicate displacing the $\mathrm{P}$ adsorbed to the soil solution, while the other nutrients resulted from the composition itself.

Corrêa et al. (2008) observed that the SSS increases the OM. These authors aimed to determine the levels of heavy metals and, in addition to not observing considerable levels after applications of SSS, reported that this increase in the contents of OM favors adsorption of heavy metals to this soil fraction because of the formation of complexes. Likewise, Vaca et al. (2011) observed increased levels of OM and nutrients in the soil, whereas heavy metals were reduced due to the increase of OM. Sandoval, Celis, and Morales (2011) observed that SSS amendments improved soil structural properties, and that these improvements were the result of the indirect contribution of soil OM.

In spite of appearing natural, it is possible that the addition of SSS in the soil does not result in an increase in the OM contents as such, due to the type of process applied to the waste, with there often being a recalcitrant organic fraction that makes little effective contribution to the increase in OM (Bertoncini et al. 2005; Chiaradia et al. 2009). Nevertheless, the supplementation of $\mathrm{N}$, associated with the greater rates of SSS, led to greater $\mathrm{N}$ contents in the soil, possibly due to reduction in the $\mathrm{C}$ to $\mathrm{N}$ ratio, increasing the waste mineralization rate, which was affected by the availability of the nutrient.

In accordance with the increase of the OM contents through SSS, it may be inferred that the $\mathrm{P}$ contents originating solely from the waste were low compared to the combination with the element itself because the presence of organic acids competes with the adsorption sites of $\mathrm{P}$, increasing $\mathrm{P}$ availability in the soil solution.

\section{Micronutrients}

Reduction in $\mathrm{Zn}$ contents after application of silicate has also been reported (Magalhães, Sobrinho, and Mazur 2011), although the authors did not observe significant differences in $\mathrm{Mn}, \mathrm{Cu}$, and $\mathrm{B}$. The decreases in $\mathrm{Zn}$ content are related to its insolubility in the soil, arising from the greater increase of $\mathrm{pH}$ as a result of the use of this amendment. These results are due to the chemical composition of the silicates 
through the presence of diverse oxides of numerous elements that become available in the soil (Prado and Fernandes 2001).

Linear reduction of $\mathrm{Mn}$ in the soil with the addition of SSS has also been reported (Martins et al. 2003). Chiaradia et al. (2009) have already verified SSS as an alternative to mineral fertilization to supply macro- and micronutrients to castor bean. As a result of the regular OM and also the availability of various micronutrients (Herencia et al. 2008), there may have been an interaction of the residue and OM, forming stable complexes of $\mathrm{Mn}$ and reducing its solubility temporarily.

As a result of micronutrient fertilization not having been used, it may be observed that there was a significant effect on the soil contents both from the combinations of amendments and from SSS and P, indicating that both the combinations may be considered as an alternative for supplementation of micronutrients, whether from solubilization coming from the amendments or as sources of micronutrients by means of the organic waste.

\section{Conclusions}

The steal slag as a soil acidity amendment that is more efficient than limestone, both in combination and separately, in the properties of soil acidity, SB, CEC, and BS\%.

The combinations of the amendments were similar in regard to the increase of $\mathrm{P}$ availability in the soil, while the $\mathrm{Cu}$ and $\mathrm{Zn}$ contents increased through LS, just as B and Mn increased through steal slag.

Although sewage sludge alone results in an increase in the soil contents of OM, N, $\mathrm{Mg}, \mathrm{K}, \mathrm{B}, \mathrm{Cu}, \mathrm{Zn}$, and $\mathrm{Fe}$, the low $\mathrm{P}$ content in the waste requires $\mathrm{P}$ supplementation in combination.

\section{Funding}

This work was supported by FAPESP:11/16330-4.

\section{Orcid}

Silvia Capuani (i) http://orcid.org/0000-0003-3645-3397

João Rigon (1) http://orcid.org/0000-0003-0184-7898

\section{References}

Abreu, C. A. D., M. F. Abreu, B. Van Raij, O. C. Bataglia, and J. C. D. Andrade. 1994. Extraction of boron from soil by microwave heating for ICP OES determination. Communications in Soil Science and Plant Analysis 25:3321-33. doi:10.1080/00103629409369267.

Alcarde, J. A., and A. A. Rodella 2003. Quality and legislations of fertilizer and acidity correction sources. In Topics in Soil Science, ed. N. Curi, J. J. Marques, L. R. G. Guilherme, J. M. Lima, A. S. Lopes and V. H. Álvares, 291-334. Viçosa, Brazil: SBCS.

Almeida Junior, A. B., F. A. Oliveira, J. F. Medeiros, and M. K. T. Oliveira. 2009. Effects of phosphorus doses in initial development of the castor bean. Revista Caatinga 22:217-21.

Backes, C., L. T. Büll, L.J.G. Godoy, R.L. V Bôas, C.P. Lima, and E. C. Pires. 2009. Use of sludge sewage in carpets production of esmeraldagrass. Ciência Rural 39:1045-50. doi:10.1590/ S0103-84782009000400014. 
Barnes, D. J., B. S. Baldwin, and D. A. Braasch. 2009. Degradation of ricin in castor seed meal by temperature and chemical treatment. Industrial Crops and Products 29:509-15. doi:10.1016/j. indcrop.2008.09.006.

Bertoncini, E. I., V. D'orazio, N. Senesi, and M. E. Mattiazzo. 2005. Fluorescence analysis of humic and fulvic acids from two Brazilian Oxisols as affected by biosolid amendment. Analytical and Bioanalytical Chemistry 381:1281-88. doi:10.1007/s00216-005-3054-2.

Briedis, C., J. C. D. M. Sá, E. F. Caires, J. D. F. Navarro, T. M. Inagaki, A. Boer, A. D. O. Ferreira, C. Quadros Neto, L. B. Canalli, and J. B. D. Sandos. 2012. Changes in organic matter pools and increases in carbon sequestration in response to surface liming in an oxisol under long-term notill. Soil Science Society of America Journal 76:151-60. doi:10.2136/sssaj2011.0128.

Brito Neto, J. F. D., L. T. Büll, E. D. M. Beltrão, J. P. G. Rigon, and V. Sofiatti. 2014. Absorption and critical levels of phosphorus in castor bean shoots grown in different soil classes. Semina 35:239-50.

Brum, B., S. L. Lopes, L. Stock, A. D. Lucio, P. H. Oliveira, and M. Milani. 2011. Canonical correlation between variables seed, seedling, plant and grain yield in castor bean. Ciência Rural 41:404-11. doi:10.1590/S0103-84782011000300007.

Carvalho-Pupatto, J. G., L. T. Büll, and C. A. C. Crusciol. 2004. Soil chemical attributes, root growth, and rice yield according to slag application. Pesquisa Agropecuária Brasileira 39:1213-18. doi:10.1590/S0100-204X2004001200008.

Castro, G. S. A., and C. A. C. Crusciol. 2013. Yield and mineral nutrition of soybean, maize, and Congo signal grass as affected by limestone and slag. Pesquisa Agropecuária Brasileira 48:673-81. doi:10.1590/S0100-204X2013000600013.

Chiaradia, J. J., M. K. Chiba, C. A. D. Andrade, C. D. Oliveira, and A. Lovorenti. 2009. Yield and plant nutrition of castor bean in crop rotation with sugarcane in a sewage-sludge-treated soil. Revista Brasileira de Ciência do Solo 33:701-9.

Colodro, G., and C. R. Espindola. 2006. Fertility changes in a degraded latosol due to sewage sludge application. Acta Scientiaum Agronomy 28:1-5.

CONAMA - National Environmental Council. 2006, 29 August. Resolution CONAMA no. 375. Management of waste and hazardous products: Use. Brazilia, Brazil: Official Diary of the Union.

Corrêa, J. C., L. T. Büll, C. A. C. Crusciol, and M. A. Tecchio. 2008. Surface application of flue dust, aqueous lime, sewage sludge, and limestone on soybean crop. Pesquisa Agropecuária Brasileira 43:1209-19. doi:10.1590/S0100-204X2008000900016.

Corrêa, J. C., E. E. Freitag, L. T. Büll, C. A. C. Crusciol, D. M. Fernandes, and R. Marcelino. 2009. Surface application of limestone and different residues on soybean grown in no-till system. Bragantia 68:1059-68. doi:10.1590/S0006-87052009000400027.

FAOSTAT. 2011. Food and agriculture organization of the United Nations. Rome: FAO. http:// faostat.fao.org/.

Herencia, J. F., J. C. Ruiz, E. Morillo, S. Melero, J. Villaverde, and C. Maqueda. 2008. The effect of organic and mineral fertilization on micronutrient availability in soil. Soil Science 173:69-80. doi:10.1097/ss.0b013e31815a6676.

Léles, E. P., D. M. Fernandes, J. I. C. D. Silva, and L. A. A. Fumes. 2010. Interaction of lime and zinc levels in the morphologic characteristics and production components of castor bean plants. Acta Scientiarum Agronomy 32:501-9.

Magalhães, M. O. L., N. M. B. A. Sobrinho, and N. Mazur. 2011. Use of industrial waste to reduce the toxicicity of cadmium and zinc in contaminated soil. Ciência Florestal 21:219-27.

Malavolta, E. 2006. Manual of mineral nutrition s plants. São Paulo, Brazil: Editora Agronômica Ceres.

Martins, A. L. C., O. C. Bataglia, O. A. Camargo, and H. Cantarella. 2003. Corn yield and uptake of $\mathrm{Cu}, \mathrm{Fe}, \mathrm{Mn}$, and $\mathrm{Zn}$ from sewage-sludge-amended soil with and without liming. Revista Brasileira de Ciência do Solo 27:563-74. doi:10.1590/S0100-06832003000300018.

Oliveira, J. P. B., J. C. Lopes, R. S. Alexandre, A. P. D. S. Jasper, L. N. D. Santos, and L. B. D. Oliveira. 2009. Effect of sewage sludge on the initial development of two castor bean cultivars in two different soil types. Engenharia Ambiental 6:174-80. 
Prado, R. M., E. L. M. Coutinho, C. G. Roque, and M. L. P. Villa. 2002. Evaluation of slag and calcareous rocks as corrective of the acidity of the ground in the culture of lettuce. Pesquisa Agropecuária Brasileira 37:539-46. doi:10.1590/S0100-204X2002000400016.

Prado, R. M., and F. M. Fernandes. 2001. Effect of slag and limestone on the availability of phosphorus of an Oxisol planted with sugarcane. Pesquisa Agropecuária Brasileira 36:1199204. doi:10.1590/S0100-204X2001000900014.

Pulz, A. L., C. A. C. Crusciol, L. B. Lemos, and R. P. Soratto. 2008. Silicate and limestone effects on potato nutrition, yield and quality under drought stress. Revista Brasileira de Ciência do Solo 32:1651-59. doi:10.1590/S0100-06832008000400030.

Quaggio, J. A., B. Van Raij, and E. Malavolta. 1985. Alternative use of the SMP buffer solution to determine lime of soils. Communications in Soil Science and Plant Analysis 16:245-60. doi:10.1080/00103628509367600.

Raij, B. V., J. C. Andrade, H. Cantarella, and J. A. Quaggio. 2001. Chemical analysis for evaluation of tropical soil fertility. Campinas, Brazil: IAC.

Ramos, L. A., A. Nolla, G. H. Korndörfer, H. S. Pereira, and M. S. Camargo. 2006. Reactivity of soil acidity correctives and conditioners in lysimeters. Revista Brasileira de Ciência do Solo 30:849-57.

Reddy, K. R., and S. K. Matcha. 2010. Quantifying nitrogen effects on castor bean (Ricinus communis L.) development, growth, and photosynthesis. Industrial Crops and Products 31:185-91. doi:10.1016/j.indcrop.2009.10.004.

Sandoval, M. A., J. E. Celis, and P. Morales. 2011. Structural remediation of an alfisol by means of sewage sludge amendments in association with yellow serradela (Ornithopus compressus L.). Journal of Soil Science and Plant Nutrition 11:68-78. doi:10.4067/S071895162011000100006.

SAS Institute. 2009. Statistical analysis system institute: Release 9.2. Cary, NC: SAS.

Severino, L. S., L. A. Dick, M. Baldanzi, M. J. D. Cândido, G. Chen, W. Crosby, T. D. Xiaohua, P. Lakshmamma, C. Lavanya, O. L. T. Machado, T. Mielke, M. Milani, T. D. Miller, J. B. Morris, M. A. A. Navas, D. J. Soares, V. Sofiatti, M. L. Wang, M. D. Zanotto, and H. Zieler. 2012. A review on the challenges for increased production of castor. Agronomy Journal 104:853-8804. doi:10.2134/agronj2011.0210.

Severino, L. S., G. B. Ferreira, C. R. D. A. Moraes, T. M. D. S. Gondim, W. S. D. A. Freire, D. A. D. Castro, G. D. Cardoso, and N. E. D. M. Beltrão. 2006. Growth and yield of castor bean fertilized with macronutrients and micronutrients. Pesquisa Agropecuária Brasileira 41:56368. (in Portuguese). doi:10.1590/S0100-204X2006000400003.

Soil Survey Staff. 2010. Keys to soil taxonomy, 11th ed. Washington, DC: US Government Printing Office.

Soratto, R. P., and C. A. C. Crusciol. 2008. Dolomite and phosphogypsum surface application effects on annual crops nutrition and yield. Agronomy Journal 100 (2):2008. doi:10.2134/ agrojn12007.0120.

Tedesco, H. J., S. J. Volkweiss, and H. Bohnen. 1985. Soil and plant analysis and other materials (Technical Bulletin 5). Porto Alegre, Brazil: UFRGS Press.

Vaca, R., J. Lugo, R. Martínez, M. V. Esteller, and H. Zavaleta. 2011. Effects of sewage sludge and sewage sludge compost amendment on soil properties and Zea mays L. plants (heavy metals, quality, and productivity). Revista Internacional de Contaminación Ambiental 27:304-11. 